\title{
УДОСКОНАЛЕННЯ ОРГАНІЗАЦІЇ НАДАННЯ СОЦІАЛЬНИХ ПОСЛУГ СПЕЦІАЛІСТАМ ФАРМАЦІї
}

\author{
(C) М. В. Зарічкова \\ Інститут підвищення кваліфрікації спеціалістів фрармації Національного \\ фрармацевтичного університету, Харків
}

\begin{abstract}
Резюме: розглянуто основні компоненти системи надання соціальних послуг спеціалістам фрармації, а саме якість, моніторинг, контроль і оцінювання соціальної послуги. Проаналізовано соціальну послугу як економічну категорію та окреслено основні її властивості. Наведено відмінності соціальної послуги від матеріальної допомоги. Теоретично обґрунтовано необхідність удосконалення ряду термінів, зокрема «соціальна послуга», «моніторинг соціальних послуг», «якість соціальної послуги для спеціалістів фрармації» тощо. Розроблено алгоритм моніторингу, контролю та оцінювання соціальної послуги. Запропоновано розглядати ці компоненти як ланцюг «Моніторинд соціальної послуги (МСП) - Контроль соціальної послуги (КСП) - Оцінювання соціальної послуги (ОСП)». Досліджено законодавчий супровід організації надання соціальних послуг та на її основі запропоновано розробити єдиний стандарт соціальних послуг для спеціалістів фрармації.
\end{abstract}

Ключові слова: соціальний захист спеціалістів фрармації, фрармацевтична галузь, соціальна послуга, моніторинг соціальної послуги, контроль соціальної послуги, оцінювання соціальної послуги.

Вступ. Важливим аспектом у наданні соціальних послуг (СП) спеціалістам фрармації є здійснення інституційного аналізу діяльності сектора виробництва СП відповідної адміністративно-територіальної одиниці. Особлива увага при цьому повина приділятися вивченню ролі держави у формуванні й розвитку сектора СП; вивченню обсягу і структури сектора СП відповідної адміністративно-територіальної одиниці, механізмів і форм взаємодії його елементів, потенціалу і ресурсів потенційних організацій $з$ надання необхідних СП. Для цього необхідно провести всебічне дослідження і детальний опис сектора СП. Аналіз сфрери надання СП може бути корисним для виявлення соціальних груп спеціалістів фармації, які на сьогодні відчувають потребу у соціальному захисті, i відповідних СП [1, 2].

Методи дослідження. Основою досліджень слугували вимоги законодавчих і нормативних актів до системи надання СП в Україні; вітчизняні наукові досягнення з організації та економіки фрармації. В ході дослідження використано сучасні наукові методи: порівняння (узагальнення законодавчої бази з надання СП), логічний (дослідження динаміки змін у системі надання СП), історичний тощо.

Ми проаналізували існуючі наукові публікації іноземних та вітчизняних авторів, які висвітлювали питання, пов'язані з соціальним захистом. Так, проблеми соціального забезпечення населення досліджували, зокрема, вітчизняні науковці - А. А. Котвіцька, О. В. Посилкіна, А. С. Немченко та ін. Аналіз літе- ратурних джерел показав, що увагу до застосування СП в Україні почали приділяти досить недавно, а досвід надання СП спеціалістам фрармації $€$ інноваційним. Дослідивши розвиток системи застосування СП для спеціалістів фрармації в Україні, можна зробити висновок, що в нашій країні це досить молодий, але вкрай актуальний напрямок, який має перспективне майбутнє і суттєво поліпшить соціальний захист працівників фрармацевтичної галузі.

Результати й обговорення. В Україні розвиток недержавного сектора соціального обслуговування відбувається вкрай повільними темпами. Це пов'язано з недосконалістю нормативної правової бази, яка не дозволяє розвивати недержавне соціальне обслуговування, зокрема з урахуванням галузевої специфіки. Розвиток недержавного сектора в системі соціального захисту спеціалістів фрармації (СЗСФ) України $€$ соціальною проблемою, яка потребує негайного вирішення. Потреба в альтернативній соціальній допомозі для спеціалістів фрармації існує вже давно, але належні умови для її здійснення досі не створені [1].

Розвинені країни світу застосовують різні моделі надання соціального обслуговування населення, які $€$ перспективними для застосування в Україні. Закордонний досвід застосування недержавного сектора для надання СП свідчить про значні здобутки в цьому питанні. Наприклад, у країнах Європи і США недержавний сектор займає значну частину в системі соціального обслуговування населення й іноді переважає над державним. В таких країнах, як США, Да-

ISSN 2312-0967. Фармацевтичний часопис. 2015. № 3 
нія, Греція основними видами недержавних установ $€$ установи, які належать різним суспільним, некомерційним організаціям. В Нідерландах, Німеччині, Північній Ірландії, Іспанії, Австрії основними видами недержавних установ $€$ такі, що належать різним приватним підприємцям, промисловим бізнесменам, виробничим корпораціям. Функціонування цих установ здійснюється за єдиними національними стандартами та нормативно-правовими документами в межах соціальної політики відповідної країни. Координацію і контроль діяльності здійснює уповноважений орган державної влади країни.

Так, у США участь держави у вирішенні соціальних проблем незначна, а соціальна відповідальність покладена на недержавні благодійні організації, фонди, профспілки тощо. Тобто завдання уряду в галузі управління соціальним захистом в США полягає не тільки в управлінні підвідомчими йому установами соціального захисту, а й у координації дій місцевої влади і громадських організацій та обліку їх зусиль у розробці національної соціальної політики.

У Данії забезпечується високий рівень соціального обслуговування населення і СП надаються відповідно до Акту про соціальну допомогу від 1976 р., який акумулював у собі основні елементи соціального законодавства Данії. Він включає, насамперед, безкоштовне надання СП, які фрінансуються за рахунок оподаткування центральним і місцевим урядами. Вирішення питань соціального обслуговування в Данії чітко розмежовані між рівнями влади, а саме: влада графств і влада на місцях.

Соціальний захист населення Німеччини має розвинену систему соціального страхування від різних видів ризиків: тимчасова втрата працездатності, інвалідність, безробіття, смерть тощо. Держава $є$ рівноправним партнером соціального страхування спільно з роботодавцем, її головною фрункцією $є$ контроль цільового витрачання державних коштів.

У Північній Ірландії основу соціального захисту складають соціальні стандарти, які затверджуються законами країни. Основними напрямками діяльності $€$ : управління медичним і соціальним доглядом відповідно до прийнятих стандартів; розробка програм розвитку (підвищення якості, кваліфікації); забезпечення системи поділу відповідальності тощо [2, 3].

Необхідно зазначити, що в усіх згаданих країнах право на надання СП, гарантованих державою, отримується на основі соціального конкурсу. Як правило, в недержавних установах послуги дешевше, ніж у державних. Однак отримувачі прагнуть користуватись послугами саме державних установ, тому що якість СП у них вище.

Отже, специфіка моделей соціального обслуговування населення в різних зарубіжних країнах може стати основою для побудови ефективної моделі системи СЗСФ в Україні. Насамперед, це децентралізація, перекладання повноважень здійснення СЗСФ на органи місцевого самоврядування, розвиток недержавного сектора, поряд 3 цим встановлення соціальних нормативів, бюджету та вартості СП на місцевому рівні, розвинена система застосування інформаційних технологій. Тому важливо мати чіткий розподіл повноважень між рівнями влади на місцях, активна участь спеціалістів фрармації, громадських організацій, недержавного сектора в розробці та проведенні соціальної політики у фармацевтичній галузі.

Проаналізувавши основні заходи, що сприяють ринковим перетворенням у сорері надання СП і спрямовані на підвищення ефективності СЗСФ, нами були виділені найбільш актуальні, а саме: організація маркетингу потреб у СП; стандартизація соціального обслуговування; розробка цінового механізму фрінансування СП; створення системи надання СП на конкурсній основі; удосконалення механізму контролю якості надаваних СП; залучення недержавних організацій до надання СП тощо. Виконання цих заходів сприятиме створенню керованого ринку СП, що, в свою чергу, підвищить якість СЗСФ та надасть змогу його реалізації в аптечних закладах незалежно від місця розташування - в місті чи селі. Для вирішення цих питань необхідно узгодити термінологічне визначення СП $[4,5]$.

Однак термін «послуга» досі не має одностайного тлумачення в науковій літературі і законодавстві України. Наприклад, термінологічне визначення СП наведено у Законі України «Про соціальні послуги» № 966-IV від 19.06.2003 р. в ст. 1, а саме: «соціальна послуга - це комплекс заходів із надання допомоги особам, окремим соціальним групам, які перебувають у складних життєвих обставинах і не можуть самостійно їх подолати, з метою розв'язання їхніх життєвих проблем». Державний комітет статистики України визначає «послугу» як результат економічної діяльності, який не набуває матеріально-речової форми і задовольняє певні потреби як особисті, так і колективні. Всі термінологічні визначення не розкривають економічної і соціальної складової СП. У закордоній літературі застосовують термін «послуга» у сенсі нематеріальної діяльності. Тобто це - дія або вигода, які організація - надавач послуг може запропонувати отримувачу за гроші або інші цінності [6-9].

Виходячи з вищезазначеного термінологічне визначення СП потребує узагальнення та перосмислення як з наукової точки зору, так і практичного застосування. Нами пропонується введення терміну СП з урахуванням усіх критеріальних особливостей, які узагальнені в таблиці 1 [2, 10, 11].

Компілюючи всі вищезазначені критеріальні особливості СП з таблиці 1, ми пропонуємо наступне термінологічне визначення «соціальна послуга для спеціалістів фрармації» - це результат соціальноекономічної діяльності надавача (організація, фрізична особа тощо), який не набуває матеріально-речової форми, і спрямований на спеціалістів фрармації, які

ISSN 2312-0967. Pharmaceutical review. 2015. № 3 
Організація роботи аптечних підприємств

Organization of pharmaceutical structures' work

Таблиця 1. Основні критеріальні особливості СП

\begin{tabular}{|c|c|c|c|}
\hline $\begin{array}{l}\text { № } \\
3 / \Pi\end{array}$ & Критерій & Коротка характеристика & Особливості \\
\hline 1 & $\begin{array}{l}\text { Нематеріаль- } \\
\text { ність }\end{array}$ & $\begin{array}{l}\text { Неможливість } \\
\text { продемонструвати та надати } \\
\text { грошову оцінку СП до її } \\
\text { отримання }\end{array}$ & $\begin{array}{l}\text { - } \text { неможливість патентування СП; } \\
\text { - } \text { неможливість інвентаризації СП; } \\
\text { - } \text { неможливість попереднього демонстрування СП; } \\
\text { - складність оцінювання СП; }\end{array}$ \\
\hline 2 & $\begin{array}{l}\text { Комплексність } \\
\text { виробництва та } \\
\text { споживання }\end{array}$ & $\begin{array}{l}\text { Неможливість відокремити } \\
\text { СП від її надавача (послуга } \\
\text { водночас надається та } \\
\text { споживається) }\end{array}$ & $\begin{array}{l}\text { - неможливість впливу отримувачів СП як на } \\
\text { процес її отримання, так і на її надавача; }\end{array}$ \\
\hline 3 & Мінливість & $\begin{array}{l}\text { Якісні та кількісні } \\
\text { характеристики СП можуть } \\
\text { змінюватися залежно від її } \\
\text { надавача }\end{array}$ & $\begin{array}{l}\text { - } \quad \text { залежність якісного та кількісного результату СП } \\
\text { від її надавача; } \\
\text { валежність якості СП від зовнішніх фракторів } \\
\text { впливу (зміна законодавчого поля тощо); } \\
\text { в відсутність єдиних стандартів СП; }\end{array}$ \\
\hline 4 & $\begin{array}{l}\text { Однократність } \\
\text { застосування }\end{array}$ & $\begin{array}{l}\text { Неможливість перепродажу } \\
\text { або повернення СП }\end{array}$ & $\begin{array}{l}-\quad \text { відсутність єдиного реєстру СП; } \\
-\quad \text { складність узгодження за часом пропозиції та } \\
\text { попиту на СП; }\end{array}$ \\
\hline 5 & $\begin{array}{l}\text { Відсутність } \\
\text { власності }\end{array}$ & $\begin{array}{l}\text { Отримувач має доступ до СП } \\
\text { тільки протягом часу її надання }\end{array}$ & $\begin{array}{l}\text { - неможливість офрормлення права власності на } \\
\text { отриману СП; }\end{array}$ \\
\hline
\end{tabular}

перебувають у складних життєвих обставинах та потребують сторонньої допомоги 3 метою поліпшення або відтворення їх життєдіяльності, соціальної адаптації та повернення до повноцінного життя.

Введення такого терміну СП необхідне для зняття існуючих суперечень в законодавчому визначенні СП, яке трактує СП як різновид матеріальної допомоги. Таке уточнення надасть можливість відповідним адміністративно-територіальним одиницям сорормувати дієву та ефективну систему надання СП, а не імітувати цю роботу за рахунок надання матеріальної допомоги, на виплату якої, як завжди, не вистачає бюджетних коштів.

Спеціалістам орармації, отримувачам СП, та громадським організаціям, які контролюють надання СП, треба знати сутність СП і вимагати від відповідних державних і недержавних служб надання СП, відокремлено від матеріальної допомоги, яка до СП не має ніякого відношення.

Основна властивість СП, як економічної категорії, а саме її нематеріальність, значно ускладнює визначення якості цієї послуги. На сьогодні інструментів, які б вимірювали безпосередню діяльність людини при наданні СП, ще не створено. Це означає, що якість СП можна визначити лише опосередковано: опитуванням (інтерв'юванням) отримувачів СП, спираючись на думку незалежних експертів або спостеріганням за опосередкованими ознаками отримання СП споживачами [12].

Існують два поняття якості СП: якість соціального обслуговування і якість безпосередньо самої СП. Оскільки якість СП безпосередньо визначити неможливо, під цим терміном розуміють якість надання СП. Про це свідчить зокрема те, що законодавчо термін «якість соціальної послуги» не визначений, а Закон
України «Про соціальні послуги» (Ст.1) узаконює показники саме надання якості СП. Так, під показниками якості СП розуміється сукупність показників, які використовуються для оцінювання діяльності суб'єктів, що надають СП, які ґрунтуються на позитивній результативності СП відносно її одержувачів і ступеня задоволення їх потреби в цих послугах $[7,13]$.

Таким чином, ми пропонуємо використання терміну «якість сочіальної послуги» як сукупності характеристик, які відображають здатність конкретної наданої СП відповідати потребам та інтересам їх відповідних одержувачів. До якісних показників СП можна віднести: ступінь задоволеності отримувачів; довіру; своєчасність; доступність; зручність; точність; безвідмовність; повагу; безпеку.

До якісного показника можна віднести постійність - це коли однотипні СП надаються систематично та однакової якості для усіх отримувачів.

За результатами нашого дослідження було встановлено, що законодавчо визначеного тлумачення терміну «моніторинг» не існує, не зважаючи на те, що цей термін постійно використовується в усіх нормативно-правових актах. На нашу думку, перед вживанням будь-якого терміну необхідно давати його термінологічне тлумачення для єдиного розуміння його сенсу [7].

У нашому дослідженні під терміном «моніторинг» розуміється безперервне стеження за яким-небудь процесом 3 метою виявлення його відповідності бажаному результату, визначених критеріїв або тенденцій розвитку. Підсумовуючи наведене вище, можна стверджувати, що «моніторинг соціальних послуг» - це постійний і систематичний збір інформації про надання СП. Моніторинг здійснюється як в інтересах, так і на замовлення організацій (установ),

ISSN 2312-0967. Фармацевтичний часопис. 2015. № 3 
які надають СП, контролюючих організацій і установ, у тому числі і громадських. Моніторинг СП здійснюється для визначення відповідності бажаному результату, законодавчим, нормативно-розпорядчим актам або тенденцій розвитку і прийняття відповідних корегуючих дій. Цим і визначається необхідність такого моніторингу та його взаємозв'язок 3 контролем та оцінюванням, алгоритм якого наведено на рисунку $1[2,7]$.

На рисунку 1 показано взаємодію компонентів ланцюга «Моніторинг СП - Контроль СП - Оцінювання СП». У ланцюгу «Моніторинг СП - Контроль СП Оцінювання СП» важливе місце займає «оцінювання якості соціальної послуги». Оцінювання - це ціннісне судження, будь-яке висловлювання, що містить позитивне чи негативне ставлення до якості СП.

Дослідження взаємодії процедур моніторингу, контролю і оцінки ефективності СП показує, що головною рисою працездатності такої системи соціального обслуговування $€$ наявність зворотного зв'язку між процедурами надання СП і оцінкою якості їх надання. Тобто висновки оцінки та контролю лягають в основу коригування надання СП, удосконалення та підвищення їх якості через проведення постійного спостереження - моніторингу [3-5, 7].

Враховуючи вищезазначене вважаємо за необхідне розроблення Стратегії реформування системи надання СП, яка буде передбачати створення незалежних інспекцій та запровадження громадського моніторингу якості СП, а також залучення до планування та надання СП, проведення моніторингу суб'єктів, що надають СП. Сутність моніторингу надання СП спеціалістам фрармації розкривається на рисунку 2 [2].

Як видно з рисунка 2, необхідно привернути увагу до такої складової моніторингу, як «визначення технології збору і обробки інформації». Насамперед через те, що залежності від вибору технології, контролюючі організації можуть отримати інформацію, яка буде об'єктивною і відповідати завданням цієї організації. Для збору і обробки інформації при проведенні моніторингу можливо використовувати основні п'ять методів [7-9]:

1. Спостереження, яке може бути фрормальним неформальним. Формальне спостереження проводиться офріційною організацією, як правило, надавачем послуг за визначеними цілями, правилами і методологією, а також на окремі замовлення суб'єктів моніторингу. Неформальне спостереження - проводиться з залученням незалежного оцінювача, який спостерігає за наданням СП у різних умовах упродовж певного проміжку часу різними надавачами послуг. Воно має переваги щодо оперативності інформації надання послуги, але має вади суб'єктивності спостереження, тому що інфрормацію надає сам спостерігач.

2. Опитування. Збір інформації безпосередньо у суб'єктів надання та отримання СП заздалегідь визна- ченою структурованою анкетою опитування, яка містить питання, що цікавлять замовника опитування.

3. Інтерв'ювання. Збір інорормації безпосередньо у суб'єктів надання та отримання СП за здалегідь визначеною темою з метою отримання думки особи, яка інтерв'юється щодо значення чи визначення конкретних показників СП та їх надання.

4. Письмове анкетування. Такий вид збору інформації відрізняється від опитування тим, що не потребує особистої присутності респондента. Він $є$ більш точним, тому що дає змогу підготувати більш обґрунтовану відповідь, ніж спонтанна відповідь при опитуванні.

5. Письмове тестування. Тестування звичайно застосовується для визначення придатності об'єкта тестування для виконання тих чи інших функцій. Тестування можуть, а інколи і повинні, проходити практично всі суб'єкти соціального обслуговування, крім отримувачів СП.

Таким чином, організаціям, які будуть здійснювати моніторинг, необхідно мати на увазі такий науковопрактичний підхід до організації моніторингу якості СП, які надаються спеціалістам фрармації:

1. Визначення показників СП, які підлягають моніторингу. При цьому їх кількість повинна бути якнайменша, а визначення стану СП вони повинні висвітлювати найбільш повно.

2. Визначення технології збору і обробки інфрормації, яка необхідна для спостереження і визначення стану системи СП спеціалістам фрармації відповідної адміністративно-територіальної одиниці.

3. Визначення складових механізму моніторингу як сукупності процедур збору і обробки інформації, точок прийняття рішень і реагування для кореляції надання СП.

4. Визначення складових механізму моніторингу як мотиваційного механізму, тобто сукупності спеціалістів-виконавців із визначенням вимог до їх кваліфрікаційних характеристик.

5. Визначення $i$ затвердження матеріальних $i$ нематеріальних заохочень виконавців моніторингу, необхідних матеріально-технічних і фрінансових ресурсів для ефективного моніторингу СП.

6. Визначення джерел інфрормації для ведення моніторингу СП, створення баз даних щодо показників, які необхідно відстежувати.

У ході нашого дослідження було встановлено необхідність термінологічного визначення терміну «контроль якості соціальної послуги». Під цим терміном ми розуміємо спостереження за об'єктом 3 метою перевірки відповідності дійсного стану якості СП, передбаченому законами, інструкціями та іншими нормативно-правовими актами. Сутність контролю якості СП для спеціалістів фрармації розкривається на рисунку $3[2,4,7]$.

Як видно з рисунка 3, сутність кожної складової контролю якості СП зрозуміла і розписана від по-

ISSN 2312-0967. Pharmaceutical review. 2015. № 3 


\begin{tabular}{|c|c|c|c|c|c|c|c|c|}
\hline 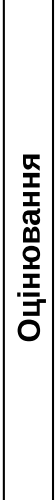 & $\rightarrow$ & 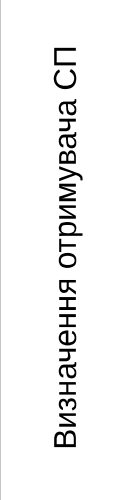 & $\rightarrow$ & 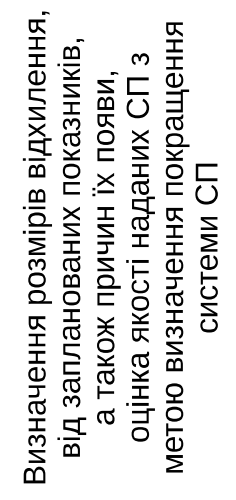 & $\rightarrow$ & 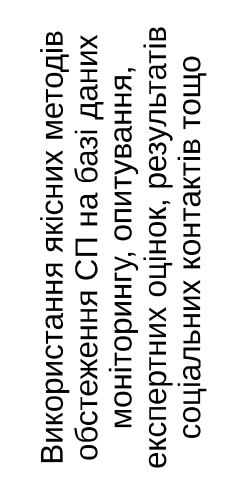 & $\rightarrow$ & 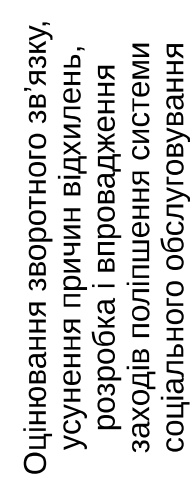 \\
\hline & & $\uparrow$ & & $\uparrow$ & & $\uparrow$ & & $\uparrow$ \\
\hline 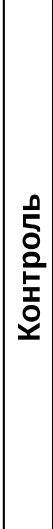 & $\rightarrow$ & 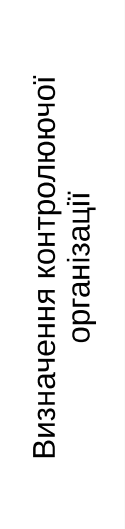 & $\rightarrow$ & 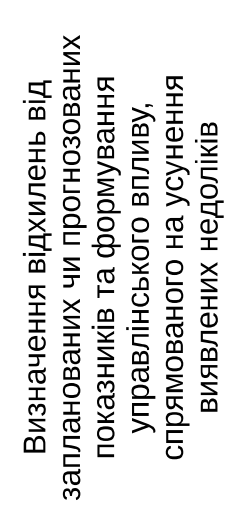 & $\rightarrow$ & 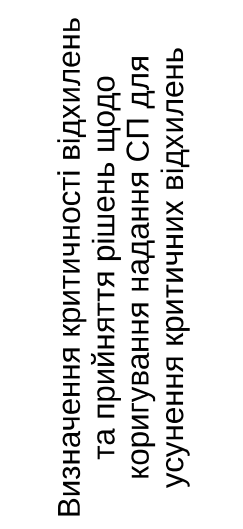 & $\rightarrow$ & 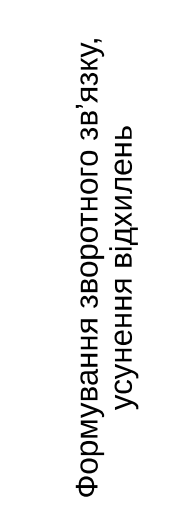 \\
\hline & & $\uparrow$ & & $\uparrow$ & & $\uparrow$ & & $\uparrow$ \\
\hline 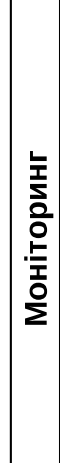 & $\rightarrow$ & 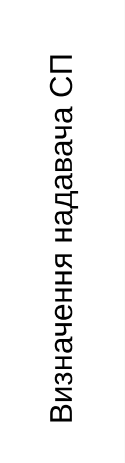 & $\rightarrow$ & 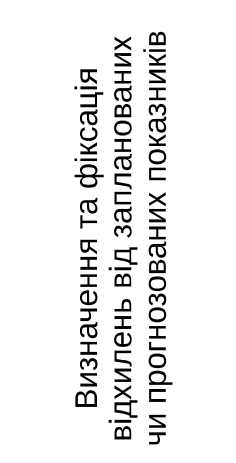 & $\rightarrow$ & 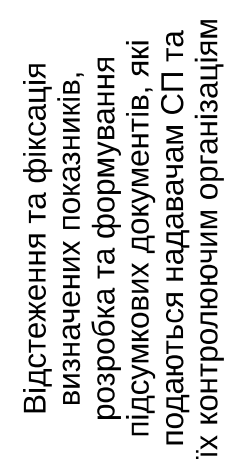 & $\rightarrow$ & 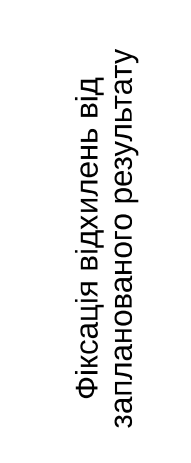 \\
\hline & & $\uparrow$ & & $\uparrow$ & & $\uparrow$ & & $\uparrow$ \\
\hline 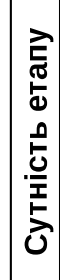 & $\rightarrow$ & 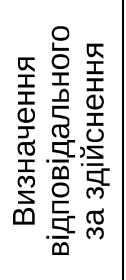 & $\rightarrow$ & 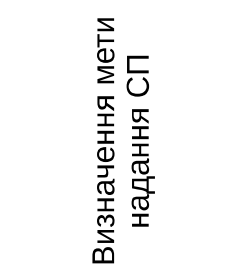 & $\rightarrow$ & 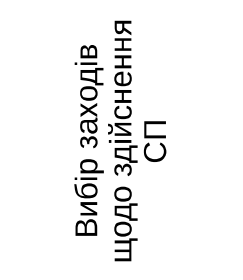 & $\rightarrow$ & 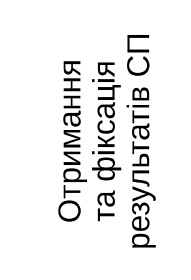 \\
\hline & & $\uparrow$ & & $\uparrow$ & & $\uparrow$ & & $\uparrow$ \\
\hline 悹 & $\rightarrow$ & - & $\rightarrow$ & $=$ & $\rightarrow$ & $\equiv$ & $\rightarrow$ & $\geq$ \\
\hline
\end{tabular}


Організація роботи аптечних підприємств Organization of pharmaceutical structures' work

\begin{tabular}{|c|c|}
\hline \multicolumn{2}{|c|}{ Складові моніторингу надання СП спеціалістам фармації } \\
\hline$\downarrow$ & $\downarrow$ \\
\hline Об'єкти моніторингу & Суб'єкти моніторингу \\
\hline$\downarrow$ & $\downarrow$ \\
\hline $\begin{array}{l}\text { - соціально-побутові СП; } \\
\text { - психологічні СП; } \\
\text { - соціально-педагогічні СП; } \\
\text { - соціально-медичні СП; } \\
\text { - соціально-економічні СП; } \\
\text { - юридичні СП; } \\
\text { - інфрормаційні СП }\end{array}$ & $\begin{array}{l}\text { - отримувачі СП; } \\
\text { - надавачі СП; } \\
\text { - контролюючі та наглядові органи влади, громадські } \\
\text { організації, які мають право контролю надання СП; } \\
\text { - групи експертів-спеціалістів соціальної сфрери }\end{array}$ \\
\hline
\end{tabular}

\section{Головні завдання моніторінгу}

$\downarrow$

\begin{tabular}{|c|c|c|}
\hline Визначення цілей & $\rightarrow$ & $\begin{array}{l}\text { Основними цілями моніторингу СП є: } \\
\text { - спостереження динаміки розвитку системи соціального обслуговування, } \\
\text { - визначення та фіксація відхилень від запланованих показників СП; } \\
\text { - надання даних для здійснення контролю та оцінки ефективності СП }\end{array}$ \\
\hline
\end{tabular}

$\downarrow$

\begin{tabular}{l|l} 
Визначення \\
показників
\end{tabular}$\rightarrow$

$\downarrow$ рольних точок

$\downarrow$

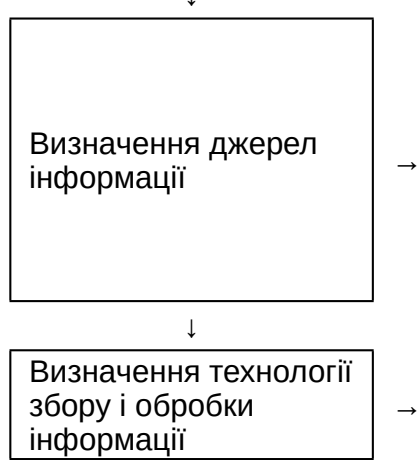

інфрормації

$\downarrow$

Визначення

користувачів

Визначення та

структуризація

підсумкового

документа
Визначення конт-

- кількісні, які мають матеріальну основу і можуть бути виміряні метричним

інструментом,

- якісні, які мають нематеріальну основу і можуть бути опосередковано оцінені експертними методами

Визначення показників СП, місця, часу та методів його виміру для оперативних дій з корегування надання СП

Джерелами інорормації для моніторингу СП можуть бути:

- нормативно-правова та організаційно-розпорядча документація;

- статистичні дані;

- дані опитування, тестування, інтерв'ювання персоналу, який надає СП;

- дані опитування, інтерв'ювання отримувачів СП;

- анкети персоналу, який надає СП та їх отримувачів;

- результати дискусій, «круглих столів», присвячених СП;

- наукова література та публікації засобів масової інформації

Методи оцінювання есрективності СП: спостереження; опитування; інтерв'ювання; письмове анкетування; письмове тестування; аналіз відповідної інформації 3 різних джерел

Визначення установ та організацій, які використовують результати моніторингу у своїй діяльності

Підсумковим документом моніторингу СП можуть бути:

- звіт про результати моніторингу,

$\rightarrow$ - доповідна записка,

- інфрормаційна записка,

- аналітична записка

Рис. 2. Алгоритм моніторингу надання СП спеціалістам фрармації.

чатку і до такої складової контролю, як «визначення підсумкового документа», зокрема, організаційнорозпорядчого документа. Так, у громадської чи благодійної організації немає права втручатись у діяльність надавача СП спеціалістам фармації, але вони мають право знати, які заходи були прийняті за ре-

зультатами контролю діяльності цього надавача СП, і відповідно реагувати, якщо, на їх думку, результати контролю були неправильно інтерпретовані. Для здійснення контролю якості СП необхідно внести деякі визначення супроводжувальної документації, а саме $[2,5,7]$ :

ISSN 2312-0967. Pharmaceutical review. 2015. № 3 
Організація роботи аптечних підприємств

Organization of pharmaceutical structures' work

\begin{tabular}{|c|c|}
\hline \multicolumn{2}{|c|}{ Складові контролю надання СП спеціалістам фармації } \\
\hline$\downarrow$ & $\downarrow$ \\
\hline Об'єкти контролю & Суб'єкти контролю \\
\hline$\downarrow$ & $\downarrow$ \\
\hline $\begin{array}{l}\text { - соціально-побутові СП; } \\
\text { - психологічні СП; } \\
\text { - соціально-педагогічні СП; } \\
\text { - соціально-медичні СП; } \\
\text { - соціально-економічні СП; } \\
\text { - юридичні СП; } \\
\text { - інфрормаційні СП }\end{array}$ & $\begin{array}{l}\text { - отримувачі СП; } \\
\text { - надавачі СП; } \\
\text { - контролюючі та наглядові органи влади, громадські } \\
\text { організації, які мають право контролю надання СП; } \\
\text { - групи експертів-спеціалістів соціальної сфрери }\end{array}$ \\
\hline
\end{tabular}

\section{Головні завдання контролю надання СП}

\begin{tabular}{|c|c|c|}
\hline $\begin{array}{l}\text { Визначення цілей } \\
\text { контролю надання Сп }\end{array}$ & $\rightarrow$ & $\begin{array}{l}\text { Основними цілями контролю надання СП є: } \\
\text { - визначення відхилень від запланованих показників СП; } \\
\text { - прийняття рішень щодо усунень критичних відхилень або приведення їх у } \\
\text { відповідність до прийнятних; } \\
\text { - впровадження прийнятих рішень }\end{array}$ \\
\hline
\end{tabular}

$\downarrow$

Визначення

показників СП, які

належать контролю

$\downarrow$

Визначення джерел

інорормації

Визначаються такі основні показники СП, які підлягають контролю:

- кількісні, які мають матеріальну основу і можуть бути виміряні метричним інструментом,

- якісні, які мають нематеріальну основу і можуть бути опосередковано оцінені експертними методами

Джерелами інфрормації для контролю СП можуть бути:

- нормативно-правова документація;

- організаційно-розпорядча документація;

$\rightarrow \quad$ - дані моніторингу;

- статистичні дані;

- дані опитування, інтерв'ю з отримувачами СП;

- наукова соціально-економічна література;

$\downarrow$

Визначення

технології збору і

обробки інформації

для контролю та

прийняття рішень

\begin{tabular}{|l|}
\multicolumn{1}{c|}{$\downarrow$} \\
\hline Визначення \\
підсумкового \\
документа
\end{tabular}

Методи збору та обробки інформації, яка необхідна для контролю СП, є:

- спостереження (моніторинг);

- інтерв'ювання;

- опитування;

- аналіз відповідної інфрормації з різних джерел;

Підсумковим документом з контролю СП можуть бути:

- звіт про результати контролю,

- доповідна записка,

- організаційно розпорядчий документ

Рис. 3. Алгоритм контролю надання СП спеціалістам фрармації.

Організаційно-розпорядчий документ - це форма службового документа, в якому міститься інформація про результати контролю СП та відповідні розпорядження щодо усунення виявлених відхилень та недопущення їх надалі. Основними організаційнорозпорядчими документами можуть бути розпорядження, доручення, вказівка, наказ, рішення.

Розпорядження - це організаційно-розпорядчий документ, призначений для регулювання і координування діяльності надавачів СП й видається з метою оперативного розв'язання конкретних організаційних або виробничих питань надавачів послуг на основі результатів контролю надання СП.

Доручення - це оперативний розпорядчий документ разового виконання.

Вказівка - це організаційно-розпорядчий документ, який видається керівником контролюючого органу і містить адресні вказівки надавачу СП щодо розв'язання окремих завдань 3 ліквідації відхилень показників цієї послуги за результатами контролю.

Наказ - це найбільш поширений організаційнорозпорядчий документ контролюючої установи, що

ISSN 2312-0967. Фармацевтичний часопис. 2015. № 3 
Організація роботи аптечних підприємств Organization of pharmaceutical structures' work

видається на підставі єдиноначальності. Текст наказу, як правило, складається $з$ двох частин: констатуючої та розпорядчої.

На рисунку 4 показана схема контролю якості СП, яка має приблизно шість етапів від визначення показни- ків якості СП до створення організаційно-розпорядчого документа фріксації результатів контролю. Таким чином, організаціям, які надають СП спеціалістам фрармації, необхідно мати на увазі такий науково-практичний підхід до організації контролю якості СП.

\begin{tabular}{|c|}
\hline Назва етапу \\
\hline$\downarrow$ \\
\hline $\begin{array}{l}\text { Визначення показників } \\
\text { якості СП }\end{array}$ \\
\hline$\downarrow$ \\
\hline $\begin{array}{l}\text { Визначення технології } \\
\text { збору та обробки } \\
\text { інорормації }\end{array}$ \\
\hline$\downarrow$ \\
\hline $\begin{array}{l}\text { Визначення складових } \\
\text { механізму контролю }\end{array}$ \\
\hline$\downarrow$ \\
\hline $\begin{array}{l}\text { Визначення і затвердження } \\
\text { матеріальних і } \\
\text { нематеріальних заохочень }\end{array}$ \\
\hline$\downarrow$ \\
\hline $\begin{array}{l}\text { Визначення джерел } \\
\text { інсрормації }\end{array}$ \\
\hline$\downarrow$ \\
\hline $\begin{array}{l}\text { Визначення організаційно- } \\
\text { розпорядчого документа }\end{array}$ \\
\hline
\end{tabular}

\begin{tabular}{|c|}
\hline Опис дій \\
\hline$\downarrow$ \\
\hline Визначаються показникі якості СП, які підлягають контролю \\
\hline
\end{tabular}

Визначаються технології збору та обробки інформації, яка необхідна для спостереження і визначення стану системи СП для спеціалістів фрармації відповідної адміністративно-теріторіальної одиниці
Визначаються складові механізму контролю як сукупності процедур збору і обробки інорормації, точок прийняття рішень і реагування для кореляції надання СП

$\rightarrow \quad \begin{aligned} & \text { Визначаються і затверджуються матеріальні і нематеріальні заохочення } \\ & \text { контролерів, необхідних матеріально-технічних і фрінансових ресурсів для }\end{aligned}$ есрективного контролю якості СП $\rightarrow \quad \begin{aligned} & \text { Визначаються джерела інформації для здійснення контролю якості СП, } \\ & \text { створення баз даних щодо показників, які необхідно контролювати }\end{aligned}$

$\rightarrow \quad \begin{aligned} & \text { Визначаються організаційно-розпорядчі документи для фріксації результатів } \\ & \text { контролю якості СП і визначення необхідних дій для усунення виявлених } \\ & \text { відхилень від встановлених величин }\end{aligned}$

Рис. 4. Схеми королю якості соціальних послуг.
Висновки. 1. Проаналізовано існуючий досвід надання соціальних послуг в Україні і за кордоном та встановлено можливості їх застосування у роботі професійних спілок та інших організацій, які займаються питаннями соціального захисту спеціалістів фрармації. Встановлено, що на сьогодні відсутній ефективний механізм надання соціальних послуг спеціалістам фрармації у відповідних адміністративнотериторіальних одиницях, тому вважаємо за необхідне створення єдиного реєстру соціальних послуг для спеціалістів орармації.

2. Проаналізовано основні критеріальні особливості соціальних послуг та надано їх коротку характеристику, висвітлено також особливості кожного критерія.

3. Проаналізовано законодавчо-нормативну базу, яка регулює систему надання соціальних послуг та виявлено необхідність вдосконалення деяких термінологічних визначеннь таких понять, як «соціальна послуга», «моніторинг соціальних послуг», «якість соціальної послуги для спеціалістів фрармації» тощо.

4. Досліджено систему соціальних послуг України та встановлено, що доцільним є вдосконалення організації моніторингу, контролю та оцінювання соціальної послуги. Для узагальнення дій в цьому напрямку запропоновано розглядати ці компоненти як ланцюг «Моніторинг соціальної послуги - Контроль соціальної послуги - Оцінювання соціальної послуги».

5. Результати досліджень показали що існує необхідність розробки системи стандартів соціальних послуг, яка б забезпечувала належний рівень життя спеціалістів фрармації та відповідала європейським стандартам. 3 огляду на це, в основу соціального захисту спеціалістів фармації необхідно закласти не прожитковий мінімум, як це визначається в чинних соціальних законах, а соціальні стандарти з урахуванням діяльності спеціалістів фрармації.

\section{Список літератури}

1. Толочко В.М.Проблемні аспекти соціального захисту спеціалістів фрармації у сучасних умовах / В. М. Толочко, М. В. Зарічкова // Вісник фрармації. - 2012. - № 2(70) . 2012. - C. 37-39.

2. Ільчук Л. І. Механізм моніторингу, контролю та оцінювання соціальних послуг в Україні [Електронний ресурс] / Л. І. Ільчук, В. М. Балаценко. - Режим доступу: http://www.cpsr.org.ua/index.php?option=com

ISSN 2312-0967. Pharmaceutical review. 2015. № 3 
Організація роботи аптечних підприємств

Organization of pharmaceutical structures' work

content \&view=article\&id=318:I-r\&catid=29:2010-06-15-1848-34\&ltemid=35.

3. Филюк Г. Рівень добробуту населення України в контексті світових стандартів / Г. Филюк // Україна: аспекти праці. - 2006. - № 7. - с. 42-44.

4. Чечель О. Пріоритетні засади формування національної концепції добробуту населення / О. Чечель // Інвестиції: практика та досвід. - 2011. - № 2. - С. 87.

5. Валовой Д. В. Социальный менеджмент / Д. В. Валовой. - М. : Академия труда и социальных отношений. $-2000 .-392$ c.

6. Соціальний захист населення: Статистичний збірник / Державний комітет статистики України. - К., 2007. $152 \mathrm{c}$.

7. Закон України Про соціальні послуги від 19.06.2003 р. № 966-IV / [Електронний ресурс] - Режим доступу: http://search.ligazakon.ua/l_doc2.nsf/link1/T030966.html.

8. Про затвердження стандартів надання послуг соціальної підтримки населенню №1 від 05.01.2015 р.: наказ Міністерства соціальної політики України / [Електронний ресурс] - Режим доступу: http://search. ligazakon.ua/l doc2.nsf/link1/RE26520.html.

9. Закон України «Про державні соціальні стандарти та державні соціальні гарантії» від 05.10.2000 р. №2017 / [Електронний ресурс] - Режим доступу: http://search. ligazakon.ua/l doc2.nsf/link1/T002017.html.

10. Лагутін В. Д. Політика заробітної плати у стратегії економічної стабілізації : монограсрія / В. Д. Лагутін. -Луцьк : «Вежа». - 2000. - 109 с.

11. Феоктистов Д. В. Методология оценки уровня и качества жизни населения / Д. В. Феоктистов // Налоги. Инвестиции. Капитал. - 2006. - № 3. - С. 115-122.

12. Горелова Н. А. Политика доходов и качество жизни населения / Н. А. Горелова. - СПб. : Питер, 2003. - 653 с. 13. Конституція України // Офріційний вісник України. 2010. - № 72/1. - 2598 c.

\section{УСОВЕРШЕНСТВОВАНИЕ ОРГАНИЗАЦИИ ПРЕДОСТАВЛЕНИЯ СОЦИАЛЬНЫХ УСЛУГ СПЕЦИАЛИСТАМ ФАРМАЦИИ}

\section{М. В. Заричковая}

Институт повышения квалификации специалистов фрармации Национального фрармацевтического университета, Харьков

Резюме: рассмотрены основные компоненты системы предоставления социальных услуг специалистам фрармации, а именно качество, мониторинг, контроль и оценка социальной услуги. Проанализирована социальная услуга как экономическая категория и выделены основные ее свойства, приведены отличия социальной услуги от материальной помощи. Теоретически обоснована необходимость усовершенствования ряда терминов, в частности «социальная услуга», «мониторинг социальных услуг», «качество социальной услуги для специалистов фрармации» и другие. Разработан алгоритм мониторинга, контроля и оценки социальной услуги. Предложено рассматривать эти компоненты как цепь «Мониторинг социальной услуги (МСУ) - Контроль социальной услуги (КСУ) - Оценка социальной услуги (ОСУ)». Исследовано законодательное сопровождение системы предоставления социальных услуг и на ее основе предложено разработать единый стандарт социальных услуг для специалистов фрармации.

Ключевые слова: социальная защита специалистов фрармации, фармацевтическая отрасль, социальная услуга, мониторинг социальной услуги, контроль социальной услуги, оценка социальной услуги.

\section{IMPROVEMENT OF THE PROVISION OF SOCIAL SERVICES FOR PHARMACY SPECIALISTS}

\section{V. Zarichkova}

Institute of Pharmacy Professionals Qualification Improvement (IPHPQI), National University of Pharmacy, Kharkiv

Summary: the main components of the system of social services for pharmacy specialists, namely quality, monitoring, control and evaluation of social services were considered. The social service as an economic category was analyzed and outlined its basic properties, in particular the differences of social services and material assistance was given. It was theoretically proved necessity of improvement some of the terms, including «social services», «monitoring of social services», «quality of social services for pharmacy specialists» and others. The algorithm for monitoring, control and evaluation of social services was developed. It is proposed to consider these components as a chain of «Monitoring of social services (MSS) - Control of Social Services (CSS) - Evaluation of Social Services (ESS)». It was investigated the legislative support of provision of social services and on its basis proposed to develop a unified standard of social services for pharmacy specialists.

Key words: social protection of pharmacy specialists, pharmaceutical industry, social services, monitoring of social services, control of social services, evaluation of social services.

ISSN 2312-0967. Фармацевтичний часопис. 2015. № 3 